\title{
Identifikasi Struktur Modal Melalui Profitabilitas, Pertumbuhan Penjualan dan Ukuran Perusahaan
}

\section{Grahita Chandrarin dan Diyah Sukanti Cahyaningsih}

Program Pascasarjana Universitas Merdeka Malang

Jl. Terusan Raya Dieng No. 59, Malang, 65145, Indonesia

\section{Info Artikel}

Sejarah Artikel:

Diterima: 5 Juni 2018

Disetujui: 27 Juni 2018

Tersedia daring: Juli 2018

Keywords:

Capital structure; Firm Size;

Pecking Order Theory;

Profitabity; Sale Growth.
ISSN (print) : 2598-7763

ISSN (online): 2598-7771 $\triangle$ Corresponding Author:

Grahita Chandrarin:

Tel. /Fax. 08123301464

E-mail:grahitac@unmer.ac.id

\section{Abtract}

This study aims to analyze the effect of profitability, sales growth and firm size on capital structure. The population of this research is basic industrial and chemical company which go public in Bursa Efek Indonesia. The observations are conducted in 2013-2016. The data source is taken from Indonesian Capital Directory Market (ICMD). Sampling technique used with purposive sampling. The sample size is 19 companies with 4 years observation period, so there are 76 observation data. Management in determining the source of financing will consider the cost or risk with a refund. In theory pecking order manajamen will expose the source of internal funding, external in the form of debt, then the issuance of shares. Profitability of the company during the year 2013-2016 shows positive. Sales increase except in 2015, where sales growth is negative. Company assets show an increase every year. Data analysis techniques use multiple linear regression. The results show that profitability and sales growth affect the capital structure. The size of the firm has no effect on the capital structure. The results support pecking order theory.

Citation: Chandrarin G dan Cahyaningsih SD.. (2018). Identifikasi Struktur Modal Melalui Profitabilitas, Pertumbuhan Penjualan, dan Ukuran Perusahaan. Accounting and Financial Review, 1 (1)

\section{Abstraks}

Penelitian ini bertujuan untuk menganalisis pengaruh profitabilitas, pertumbuhan penjualan dan ukuran perusahaan terhadap struktur modal. Populasi penelitian ini adalah perusahaan industri dasar dan kimia yang go publik di Bursa Efek Indonesia. Observasi dilakukan tahun 2013-2016. Sumber data diambil dari Indonesia Capital Directory Market (ICMD). Teknik sampling yang digunakan dengan purposive sampling. Jumlah sampel sebanyak 19 perusahaan dengan periode pengamatan 4 tahun, sehingga ada 76 data observasi. Manajemen dalam menentukan sumber pembiayaan akan mempertimbangkan biaya atau risiko dengan pengembalian dari dana tersebut. Dalam pecking order theory manajamen akan mengutakan sumber pendanaan internal, eksternal berupa hutang, kemudian penerbitan saham. Profitabilitas perusahaan selama tahun 2013-2016 menunjukkan positif. Penjualan mengalami penuingkatan kecuali pada tahun 2015, dimana pertumbuhan penjualan negatif. Aktiva perusahaan menununjukkan peningkatan setiap tahunnya. Teknik analisis data yang digunakan regresi linear berganda. Hasil penelitian menunjukkan bahwa profitabilitas dan pertumbuhan penjualan berpengaruh terhadap struktur modal. Ukuran perusahaan tidak berpengaruh terhadap struktur modal. Hasil penelitian mendukung pecking order theory.

JEL Classification: G32, G34 


\section{PENDAHULUAN}

Manajemen sebagai agent berusaha untuk mengelola perusahaan dalam upaya meningkatkan nilai perusahaan. Nilai perusahaan yang meningkat akan meningkat pula kemakmuran pemilik peru-sahaan. Manajemen akan mengambil kebijakan untuk mencapai tujuan perusahaan, yaitu meningkatnya kinerja perusahaan. Dengan kinerja perusahaan yang meningkat akan berdampak pada nilai perusahaan yang meningkat pula.

Manajemen akan merencanakan dan mengambil kebijakan dalam upaya mencapai tujuan perusahaan. Kebijakan perusahaan meliputi fnancing decision (keputusan pemenuhan kebutuhan dana), investment decision (keputusan investasi), devidend decision (pengelolaan aktiva dan kebijakan deviden). Kebijakan terkait dengan penentuan sumber dana atau kebijakan struktur modal menjadi faktor penting. Kebijakan ini terkait dengan bagaimana perusahaan menentukan sumber pendanaannya untuk menopang operasional perusahaan. Konsekuensi dari penentuan sumber dana akan terkait dengan biaya dana dan tingkat pengembalian dari dana tersebut. Sehingga kebijakan struktur modal akan berimplikasi pada kinerja perusahaan. Kebijakan struktur modal akan berdampak pada kinerja peru-sahaan (Subagyo, 2011; Nugraha, 2013; Komara, Hartoyo dan Andati, 2014; Haryanto, 2016).

Industri dimana suatu perusahaan beroperasi berdampak pada kebijakan struktur modalnya. Hal ini terkait dengan kebutuhan struktur modal untuk masing-masing industri memiliki karakteristik yang berbeda. Harmono (2010) menemukan perusahaan yang bergerak pada industri yang berbeda keadaan struktur modalnya juga berbeda.

Dalam perspektif Signaling theory, kebijakan struktur modal merupakan sinyal kepada investor yang diberikan oleh manajemen terkait dengan prospek perusahaan. Perusahaan dengan struktur modal yang besar merupakan sinyal bahwa perusahaan memiliki prospek yang baik. Perusahaan dengan prospek yang baik, cenderung menggunakan hutang sebagai sumber pembiayaan ketimbang menerbitkan saham baru. Sebaliknya perusahaan akan cenderung menerbitkan saham baru untuk membiayai operasional perusahaan, ketika prospek perusahaan kurang baik

Strutur modal menunjukkan proporsi sumber pembiayaan perusahaan antara modal dengan hutang. Perusahaan menentukan struktur modal yang optimal, sehingga akan dapat mening-katkan nilai perusahaan. Struktur modal akan terkait dengan biaya dana dan tingkat pengem-balian dari sumber dana tersebut. Perusahaan akan berusaha mengoptimalkan tingkat pengem-balian modal dengan tingkat risiko atau biaya modal yang minimimal. Pihak manajemen dalam memenuhi kebutuhan dananya harus dapat mela-kukan pilihan sumber dana yang efisien dan menguntungkan perusahaan baik untuk saat ini maupun untuk masa yang akan datang.

Kebijakan struktur modal yang optimal akan menekan munculnya konflik antara manajemen, dan pemegang saham. Pemisahan antara principal sebagai pemilik dengan manajemen sebagai agent telah menimbulkan masalah keagenan. Penggunaan hutang sebagai sumber pendanaan dalam agency theory merupakan upaya untuk mengatasi problem keagenan. Kehadiran kreditur, sebagai pihak ketiga dalam pengawasan perusahaan lebih dioptimalkan.

Penggunaan sumber dana eksternal berupa hutang dapat mengontrol perilaku manajemen dalam mengelola perusahaan. Sehingga pemegang saham tidak dirugikan. Penggunaan hutang sebagai sumber pembiayaan akan dapat berdampak positif terhadap nilai perusahaan.

Risiko menjadi pertimbangan penting bagi kreditur dalam menyalurkan dananya. Perusahaan-perusahaan dengan tingkat risiko yang tinggi cenderung akan berdampak pada hambatan untuk memperolah dana dari kreditur dan sebaliknya. Perusahaan dengan tingkat profitabilitas yang tinggi akan cenderung lebih menarik kredit-ur untuk menyalurkan ke perusahaan tersebut. Pofitabilitas perusahaan merefleksikan bagai-mana prospek perusahaan tersebut, perusahaan de-ngan profitabilitas yang tinggi akan cenderung memiliki prospek yang baik. Sebaliknya, perusa-haan dengan profitabilitas yang rendah atau bahkan negatif akan cenderung memiliki prospek yang kurang baik.

Perusahaan dengan profitabilitas yang tinggi menunjukkan perusahaan tersebut mampu membukukan laba yang tinggi. Laba dengan laba yang tinggi akan cenderung dapat menyisihkan laba dalam bentuk laba ditahan untuk menambah modal. Dalam perspekstif manajemen, perusahaan dengan profitabilitas yang tinggi akan lebih cenderung menggunakan dana dari laba ditahan sebagai sumber dana untuk membiaya operasional perusahaan. Namun, disisi lain perusahaan dengan profitabilitas yang tinggi akan memiliki 
kemampuan untuk membayar hutang yang lebih tinggi. Sehingga perusahaan dengan profit yang tinggi, memiliki potensi membiayai operasionalnya dari hutang.

Dalam Pecking Order Theory perusahaan akan lebih mengutamakan sumber dana internal ketimbang sumber dana eksternal. Teori ini dikembangkan oleh Myer (1984) dan kemudian dikembang oleh Myer dan Majluf (1984) dengan konsep asymmetric information. Perusahaan akan lebih mengutamakan sumber dana internal, yaitu dari laba ditahan, kemudian baru sumber dana hutang. Hal ini dilakukan untuk mencegah masalah asymmetric information. Sehingga perusahaanperusaha-an dengan laba yang tinggi akan akan cenderung memiliki porsi hutang yang lebih rendah. Di sisi lain perusahaan dengan tingkat profit yang tinggi akan memiliki kemampuan untuk membayar hutang yang lebih besar. Risiko kreditur akan lebih rendah ketika mengucur dananya pada dengan profit yang tinggi ketimbang pada perusahaan dengan profit yang rendah atau bahkan cenderung rugi.

Perusahaan dengan tingkat penjualan yang tinggi, akan cenderung menuntut produksi yang tinggi pula. Perusahaan dengan tingkat partumbuhan yang tinggi menuntut peningkatan jumlah produksi, sehingga kebutuhan dana perusahaan akan meningkat. Manajemen akan berusaha memenuhi kebutuhan dana yang meningkat, untuk memperlancar operasional perusahaan. Perusahaan dengan penjualan yang tinggi, maka cash flow perusahaan akan menjadi tinggi. Cash flow ini menjadi salah satu sumber pendanaan untuk operasional perusahaan.

Pertumbuhan penjualan yang meningkat, menuntut perusahaan untuk meningkatkan produksi. Untuk menopang peningkatan produksi, maka kebutuhan pembelanjaan pada alat-alat produksi juga meningkat. Jika sumber dana internal perusahaan dari laba ditahan tidak mampu mencover kebutuhan modal, maka manajemen akan cenderung menggunakan hutang. Hal ini akan berdampak pada struktur modal perusahaan. Penelitian yang meneliti pengaruh pertumbuhan perusahaan ataupun pertumbuhan penjualan terhadap struktur modal telah banyak dilakukan. Namun demikian, hasil penelitian menunjukkan hasil yang tidak konsisten. Temuan penelitian Murhadi (2011) menunjukkan bahwa pertumbuhan berpengaruh terhadap struktur modal. Penelitian Sari, Djazuli dan Aisjah (2013) menunjukkan hasil yang berbeda.

Beberapa penelitian menginvestigasi struk- tur modal. Harmono (2012) perilaku manajemen di Indonesia cenderung memanfaatkan daripada akumulasi laba ditahan dalam mendukung teori pecking order

Vries (2010) menginvestigasi pengaruh faktor ekonomi dan karakteristik perusahaan terhadap struktur modal. Sitorus (2013) yang melakukan penelitian hubungan antara struktur kepemilikan dengan struktur modal optimal pada perusahaan telekomunikasi. Hasil penelitian menunjukkan bahwa perusahaan dengan kepemilikan yang terkonsentrasi cenderung memiliki struktur modal yang optimal. Penelitian Haryanto (2012), Pujiharjanto, Nilmawati dan Gusaptono (2014), menunjukkan profitabilitas berpengaruh terhadap struktur modal perusahaan. Temuan penelitian Ruslim (2009) menunjukkan profitabilitas tidak berpengaruh terhadap struktur modal. Temuan penelitian Haryanto (2012) menunjukkan bahwa degree of operating leverage (DOL), pertumbuhan penjualan perusahaan, intensitas aktiva berpengaruh terhadap struktur modal, sedangkan stabilitas penjualan dan risiko bisnis tidak berpengaruh terhadap struktur modal. Sedangkan Ruslim (2009) menunjukkan defisit pendanaan internal dan hutang jangka panjang berpengaruh terhadap struktur modal.

Perusahaan yang kecil akan cenderung mengakses sumber-sumber pendaaan, baik itu dari kreditor maupun dari penerbitan saham. Sedangkan perusahaan besar akan lebih mudah mengakses permodalan dari hutang. Bagi kreditur lebih suka mengucurkan kredit kepada perusahaan besar ketimbang perusahaan kecil. Hal ini terkait dengan tingkat risiko pada perusahaan besar cenderung lebih rendah. Perusahaan yang besar memiliki kemampuan jaminan lebih besar, sehingga lebih dapat menyakinkan kreditur. Risiko kreditur cenderung lebih kecil ketika memberikan kredit kepada perusahaan besar dibandingkan pada perusahaan kecil.

Dalam teori assimetry information, perusahaan besar akan lebih mudah berhungan dengan kreditur dan investor. Perusahaan yang semakin besar cenderung akan memilih hutang sebagi sumber pendanaan. Krasausakaite (2011) bahwa pendanaan dengan menerbitkan saham baru merupakan sinyal negatif bagi investor.

Penelitian yang menginvestigasi hubungan antara ukuran perusahaan antara lain dilakukan Haryanto (2016) menunjukkan bahwa ukuran perusahaan berpengaruh positif terhadap struktur modal perusahaan. Namun penelitian Christianti (2006) menunjukkan ukuran perusahaan 
berpengaruh negatif terhadap struktur modal. Penelitian Gracia dan Mira (2008) menemukan bahwa semakin besar perusahaan akan cenderung memilik leverage yang semakin besar.

Penelitian yang dilakukan tentang struktur modal telah banyak dilakukan, namun demikian hasil penelitian menunjukkan hasil yang tidak konsisten. Hal ini terkait dengan kondisi, prospek dan lingkungan perusahaan. Selain itu industri dimana perusahaan tersebut bergerak, tentunya juga akan menjadi faktor pertimbangan manajemen dalam menentukan kebijakan sumber dana. Industri dimana perusahaan beroperasi akan menentukan struktur dananya. Tujuan peneltian ini untuk menganalisis pengaruh profitabilitas, pertumbuhan penjualan dan ukuran perusahaan terhadap struktur modal perusahaan.

\section{PENGEMBANGAN HIPOTESIS}

Dalam pecking order theory manajemen akan lebih mengutamakan sumber pembiayaan internal ketimbang sumber dana eksternal. Perusahaan dengan tingkat profitabilitas yang tinggi, mencerminkan perusahaan mampu membukukan laba yang tinggi pula. Perusahaan dapat menggunakan laba ditahan sebagai sumber pembiayaan perusahaan, sehingga perusahaan akan mampu menekan hutang. Perusahaan dengan profitabilitas yang tinggi, cenderung untuk membiayai kebu-tuhan dana untuk operasional perusahaan da-ri dana internal. Profitabilitas berpengaruh nega-tif terhadap struktur modal (Christianti, 2006), Prabansari dan Kusuma (2005). Wimelda dan Marlinah, 2013), Sheikh dan Wang (2011); Sari, Djazuli dan Aisjah (2013), Murhadi (2011). Hipo-tesis penelitian dapat dirumuskan sebagai berikut:

$\mathrm{H}_{1}$ : Profitabilitas berpengaruh terhadap struktur modal.

Perusahaan dengan tingkat pertumbuhan penjualan yang tinggi, maka akan mendorong peningkatan produksi. Peningkatan pertumbuhan perusahaan akan mendorong peningkatan pembiayaan perusahaan dalam upaya meningkatkan kapasitas produksi. Jika kebutuhan dana tidak mampu dicukupi dari sumber internal, maka manajemen akan lebih cenderung menggunakan sumber dana dari hutang dibandingkan dengan menerbitkan saham baru. Perusahaan menguntungkan mengambil sumber pendanaan dari hutang, pada kondisi perusahaan dengan pertumbuhan penjualan yang tinggi. Perusahaan akan dibebani biaya dana yang tetap berupan bunga pinjaman, walaupun laba perusahaan meningkat. Temuan penelitian Murhadi (2011), Eriotis (2007) dan Song (2005) menunjukkan pertumbuhan berpengaruh terhadap struktur mo-dal. Hipotesis penelitian da-pat dirumuskan sebagai berikut:

$\mathrm{H}_{2}$ : Pertumbuhan penjualan berpengaruh terhadap struktur modal.

Perusahaan dengan aset yang semakin besar akan cenderung memiliki kemampuan untuk mengcover hutang. Sehingga dengan se-makin besar perusahaan, maka perusahaan tidak mempunyai kendala untuk memperoleh pembiayaan dari hutang. Berdasarkan teori static trade off (STO), dimana pertimbangan kebijakan struktur modal perusahaan adalah berdasarkan benefit dan cost-nya, yaitu adanya keuntungan pajak dari hutang dan cost-nya berupa biaya kebangkrutan. Ukuran perusahaan akan berpengaruh terhadap struktur modal perusahaan. Risiko kebangkrutan perusa-haan dengan aset yang relatif lebih besar akan cenderung lebih kecil dibandingkan dengan perusahaan dengan aset yang lebih kecil. Ukuran perusahaan berpengaruh negatif terhadap struktur modal (Christianti, 2006; Prabansari dan Kusuma, 2005; Wimelda dan Marlinah, 2013; Wiliandri, 2011; Fachrudin (2013); Sari, Djazuli dan Aisjah, 2013; Murhadi, 2011; Haryanto, 2015). Hipotesis penelitian dapat dirumuskan sebagai berikut:

$\mathrm{H}_{3}$ : Ukuran perusahaan berpengaruh terhadap struktur modal.

\section{DATA DAN METODE}

Penelitian ini merupakan penelitian kausalitas, yaitu dengan melakukan menganalisis hubungan sebab akibat antara profitabilitas, pertumbuhan penjualan dan ukuran perusahaan dengan struktur modal. Populasi dalam penelitian ini adalah perusahaan industri dasar dan kimia yang listed di BEI. Teknik sampling yang digunakan adalah purposive sampling, dengan kriteria sebagai berikut: 1) Perusahaan sudah go public sebelum tahun 2013. 2) Perusahaan tersebut mempublikasikan laporan keuangan tahun 2013-2016. Berdasarkan kriteria tersebut jumlah sampel dalam penelitian ini sejumlah 19 perusahaan, sehingga jumlah data observasi sebanyak 76 pasang data. Sumber data penelitian diperoleh dari Indonesian Capital Market Directory yang diakses dari situs ww. idx.co.id.

Klasifikasi variabel dalam penelitian ini diklasifikasikan menjadi variabel dependen dan variabel independen. Dimana variabel independen 
meliputi profitabilitas, pertumbuhan penjualan dan ukuran perusahaan. Opersionalisasi variabel penelitian disajikan pada Tabel 1.

Secara sistematis persamaan yang dikembangkan untuk menguji hipotesis penelitian ini adalah dengan menggunakan regresi linear berganda. Persamaan regresi diformulasikan seperti

Tabel 1. Operasionalisasi Variabel pada persamaan sebagai berikut:

$$
Y=\beta_{0}+\beta_{1} X_{1}+\beta_{2} X_{2}+\beta_{2} X_{a}+e
$$

Dimana:Y: Struktur Modal; $\beta_{0}$ : Konstanta; $\beta_{1-3}$ : Koefisien Regresi; $X_{1}$ : Profitabilitas; $X_{2}$ : Pertumbuhan penjualan, $X_{3}$ : Ukuran perusahaan dan e: disturbance error.

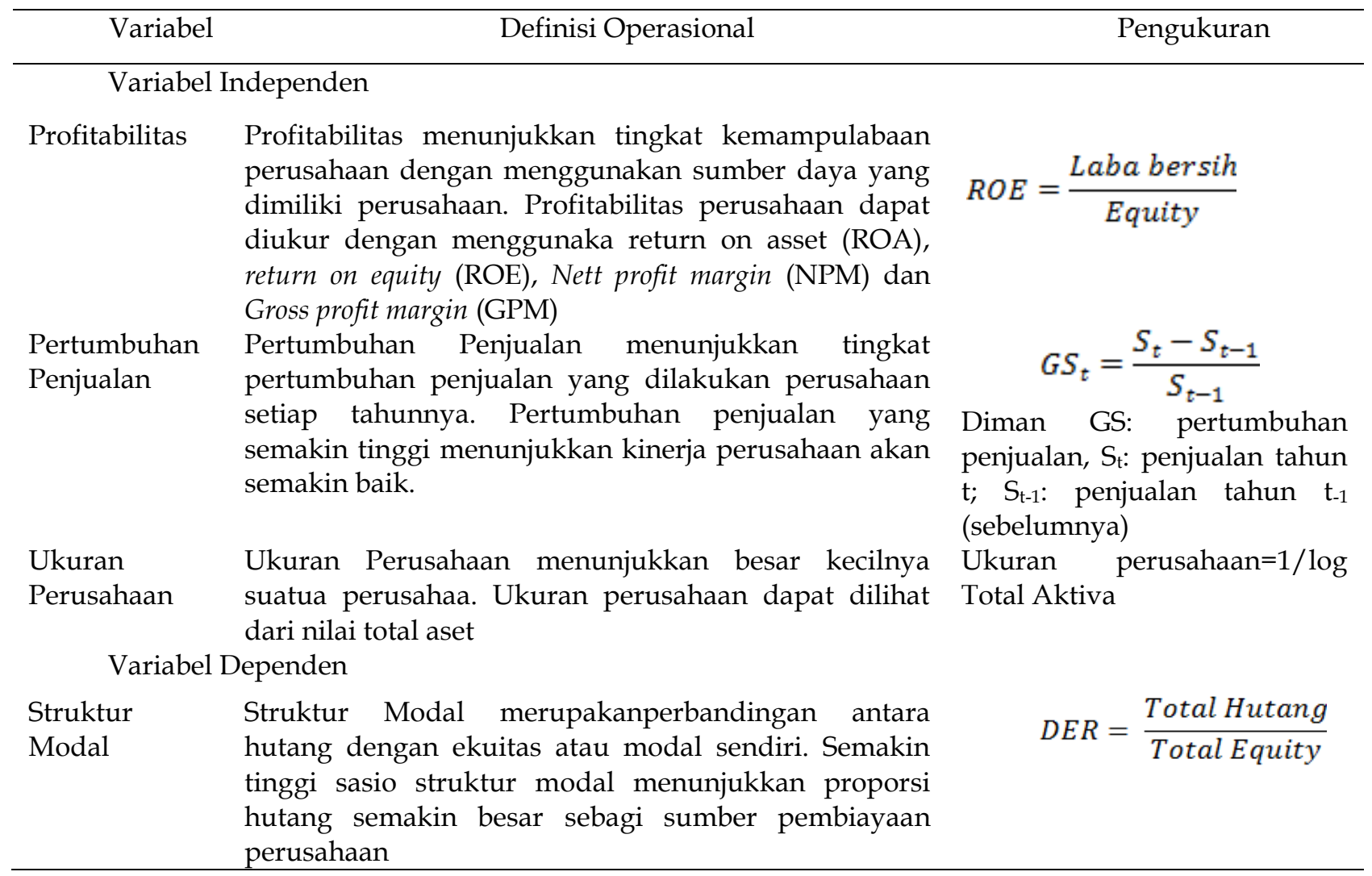

\section{HASIL}

\section{Analisis Statitistik Deskripsi}

Berdasarkan laporan keuangan perusahaan yang bergerak pada sektor industri dasar dan kimia besarnya struktur modal atau debt to equity ratio (DER), Profitabilitas (ROE), pertumbuhan penjualan dan aktiva disa-jikan pada tabel 2.

Berdasarkan tabel 2 nilai rata-rata struktur modal yang diukur dengan nilai debt to equity ratio (DER) sebesar 1,160. Dimana besarnya DER selama tahun 2013-2016 mengalami fluktuasi. Struktur modal perusahaan pada sektor industri dasar dan kimia lebih didominasi oleh hutang dibandingkan dengan modal sendiri. Rata-rata struktur hutang perusahaan pada sektor industri dasar dan kimia terbesar pada tahun 2014, yaitu sebesar 1,253. Artinya besarnya hutang perusahaan 1,253 kali dari nilai ekuitas perusahaan. Besarnya hutang perusahaan pada industri dasar dan kimia lebih besar dibandingkan dengan ekuitasnya.

Perusahaan industri dasar dan kimia selama tahun 2013-2016 rata-rata membukukan profitabilitas yang positif, artinya perusahaan manufaktur mampu membukukan laba. Tingkat proftabilitas perusahaan yang diukur dengan menggunakan return on equity (ROE) menunjukkan kecende-rungan penurunan. Rata-rata profitabilitas sebesar 8,118. Secara umum profitabilitas perusa-haan industri dasar dan kimia relatif baik. Walaupun ada beberapa perusahaan yang mengalami kerugian antara tahun 2013-2016.

Rata-rata pertumbuhan penjualan perusahaan industri dasar dan kimia relatif positif, artinya penjualan perusahaan cenderung meningkat setiap tahunnya. Penjualan mengalami penurunan cukup besar terjadi pada tahun 2015, dimana pertumbuh- 
an penjaulan -0.052. Pertumbuhan penjualan yang menurun ini berakibat pada profitabilitas yang mengalami penurunan juga poada tahun 2015. Dimana profitabilitas pada tahun 2015 menurun menjadi 5,229 dari 10,526 pada tahun 2014.

Kekayaan perusahaan yang ditunjukkan dari aset perusahaan cenderung terus mengalami peningkatan. Peningkatan aset perusahaan ini sebagai dampak dari kemampuan perusahaan industri da- sar dan kimia yang mampu membukukan laba setiap tahunnya. Pada tahun 2015 pertumbuhan penjualan mengalami penurunan, namun keadaan ini rata-rata tidak sampai membuat perusahaan mengalami kerugian. Walaupun tidak semua perusahaan yang bergerak sektor industri dasar dan kimia asetnya meningkat. Hal ini karena ada beberapa perusahaan yang mengalami kerugian, sehingga akan mengurangi ekuitasnya.

Tabel 2. Data Desktiftisi Statistik

\begin{tabular}{ccccc}
\hline Tahun & DER & ROE & GS & Aktiva \\
\hline 2013 & 1,191 & 10,565 & 0,078 & 8.327 .082 \\
2014 & 1,253 & 10,526 & 0,205 & 9.282 .856 \\
2015 & 1,021 & 5,229 & $-0,052$ & 10.913 .241 \\
2016 & 1,177 & 6,151 & 0,051 & 11.294 .261 \\
\hline Maksimum & 1,253 & 10,565 & 0,205 & 11.294 .261 \\
Minimum & 1,021 & 5,229 & $-0,052$ & 8.327 .082 \\
Rata-rata & 1,160 & 8,118 & 0,070 & 9.954 .360 \\
\hline
\end{tabular}

Sumber: www.idx.co.id diolah

\section{Hasil Pengujian Model}

Hasil analisis data berdasarkan persamaan 1 dapat ditunjukkan pada tabel 3. Pengujian regresi ini dilakukan dengan menggunakan 76 pasang data untuk perusahaan industri dasar dan kimia. Sebe- lum dilakukan analisis data, telah dilakukan pengujian normalitas data dan uji asumsi klasik, dimana data berdistribusi normal, dan memenuhi asumsi klasik, yaitu heterpskedasitas, autokorasi dan heterskedasitas..

Tabel 3. Hasil Pengujian

\begin{tabular}{llrrr}
\hline \multicolumn{1}{c}{ Variabel } & \multicolumn{2}{c}{ Koefisien } & \multicolumn{1}{r}{ Probabilitas } \\
\hline Konstanta & & 1,041 & 1,451 & 0,15600 \\
Profitabilitas & & $-0,470$ & $-3,225$ & $0,003^{*}$ \\
Pertumbuhan penjualan & & 0,423 & 2,312 & $0,027^{* *}$ \\
Ukuran Perusahaan & & $-1,562$ & $-0,421$ & 0,676 \\
\hline Jumlah & $: 76$ & & \\
$\mathrm{R}$ & $: 0,573$ & & \\
$\mathrm{R}^{2}$ & $: 0,379$ & & \\
$\mathrm{R}^{2}$ adj & $: 0,271$ & & \\
F Hitung & $: 5,710$ & & \\
Prob. F & $: 0,003$ & & \\
\hline
\end{tabular}

Keterangan: * signifikan pada level 0,01 dan ** signifikan pada level 0,05

Berdasarkan hasil pengujian pada Tabel 3 menunjukkan ukuran perusahaan yang proksikan dengan $1 / \log$ total aktiva tidak berpengaruh terhadap struktur modal. Besar kecilnya perusahaan cenderung tidak berpengaruh pada struktur modal.

Profitabilitas yang diukur dengan return on equity (ROE) berpengaruh terhadap struktur modal pada level signifikan 1 persen dengan arah berlawanan. Hal ini menunjukkan bahwa peningkatan profitabilitas perusahaan akan menurun-kan struk- tur modal perusahaan dan sebaliknya.

Pertumbuhan penjualan menunjukkan berpengaruh terhadap struktur modal. Pertum-buhan penjualan berpengaruh dengan arah positif terhadap struktur modal. Semakin tinggi pertumbuhan penjualan, maka struktur modal akan cenderung semakin meningkat dan sebaliknya.

\section{PEMBAHASAN}

Pengaruh Profitabilitas Terhadap Struktur Modal 
Profitabilitas menunjukkan kemampuan perusahaan dalam memperoleh laba dari sumber daya yang dimiliki. Semakin tinggi probabilitas suatu perusahaan menunjukkan perusahaan tersebut mampu membukukan laba yang semakin tinggi. Hasil penelitian menunjukkan bahwa profitabilitas perusahaan berpengaruh terhadap struktur modal perusahaan dengan arah yang negatif. Hal ini menunjukkan bahwa semakin tinggi profitabilitas perusahaan maka struktur modal akan cenderung menurun.

Perusahaan dengan profitabilitas yang semakin tinggi, maka perusahaan tersebut akan cenderung memiliki potensi untuk menyisihkan labanya sebagai laba ditahan yang semakin besar. Laba yang ditahan merupakan sumber pembiayaan bagi perusahaan untuk menambah modal. Sehingga perusahaan dengan laba yang ditahan yang semakin besar, akan cenderung dapat mengurangi penggunaan hutang sebagai sumber pembiayaan operasional perusahaan. Hal ini sesuai dengan pecking order theory, dimana manajemen akan cenderung lebih mengutamakan sumber pembiayaan internal dari laba ditahan daripada hutang.

Perusahaan dengan profitabilitas yang rendah atau bahkan mengalami negatif, karena perusahaan mengalami kerugian maka perusahaan akan kesulitan menyisihkan laba sebagai laba ditahan. Akibatnya perusahaan akan cenderung menggunakan sumber pembiayaan dari hutang, sehingga struktur modal akan meningkat.

Hasil penelitian ini sesuai dengan temuan penelitian (Christianti, 2006), Prabansari dan Kusuma (2005). Wimelda dan Marlinah, 2013), Sheikh dan Wang (2011); Murhadi (2011), Sari, Djazuli dan Aisjah (2013), Proença, Laureano \& Laureano (2014). Temuan penelitian ini tidak sejalan dengan penelitian Ruslim (2009), Rochmah \& Asyik (2015)

\section{Pengaruh Pertumbuhan Penjualan Terhadap Struktur Modal}

Pertumbuhan penjualan berpengaruh terhadap struktur modal, dengan arah positif. Hal ini menunjukkan bahwa peningkatan penjualan, akan cenderung mendorong perusahaan melakukan hutang untuk membiayai peningkatan produksi. Modal. Artinya perusahaan dengan pertumbuhan penjualan yang tinggi, akan lebih berani mengambil modal eksternal untuk meningkatkan meningkatkan operasi perusahaan. Dengan penjualan yang semakin tinggi diharapkan perusahaan mampu meningkatkan produksinya, untuk itu diperlukan modal tambahan yang berasal dari luar perusahaan
Perusahaan dengan penjualan yang semakin meningkat setiap tahunnya menunjukkan prospek perusahaan positif. Hasil penelitian menunjukkan bahwa pertumbuhan penjualan berpengaruh terhadap struktur modal dengan arah positif. Artinya semakin tinggi pertumbuhan penjualan suatu perusahaan, maka struktur modal perusahaan akan semakin besar. Hal ini mengindikasikan bahwa semakin besar pertumbuhan perusahaan, maka hutang perusahaan akan semakin meningkat.

Perusahaan dengan pertumbuhan penjualan yang semakin besar, akan mendorong pingkatan pula pada produksi. Pertumbuhan penjualan yang tinggi, maka perusahaan akan berupaya meningkatkan kapasitas produksi dan melakukan perluasan usaha. Kebutuhan bahan-bahan produksi maupun peralatan produksi akan meningkat. Perusahaan akan memerlukan tambahan pendanaan untuk membiayai kegiatan produksi dan invetasi tersebut.

Perusahaan dengan pertumbuhan penjualan yang pesat akan lebih mengandalkan modal eksternal, ketika sumber dana internal tidak mampu mengcover kebutuhan dana. Untuk memenuhi peningkatan dana seiring dengan pertumbuhan penjualan, perusahaan cenderung mengutamakan penerbitan obligasi daripada menerbitkan saham. Peningkatan kebutuhan dana dilakukan dalam upaya untuk memenuhi strategi kebutuhan modal kerja perusahaan yang meningkat.

Hasil penelitian ini mendukung temuan penelitian Murhadi (2011), Eriotis (2007) dan Song (2005) menunjukkan pertumbuhan berpengaruh terhadap struktur modal.

\section{Pengaruh Ukuran Perusahaan Terhadap Struktur Modal}

Hasil penelitian menunjukkan bahwa ukuran perusahaan tidak berpengaruh terhadap struktur modal perusahaan. Semakin besar perusahaan akan cenderung memiliki kemampuan untuk melakukan diversifikasi sumber pendanaan. Kemampuan diversifikasi yang semakin besar, akan cenderung perusahaan tidak hanya mengandalkan pendanaannya dari satu sumber.

Perusahaan besar akan memiliki kemampuan dan kepercayaan untuk mengakses dana dari kreditur dan penerbitan saham. Selain itu perusahaan besar juga cenderung memiliki diversifikasi sumber pendapatan yang semakin banyak, sehingga laba perusahaan dapat semakin besar. Potensi perusahaan besar untuk menyisihkan laba, sebagai laba ditahan akan cenderung semakin tinggi.

Perusahaan besar akan memiliki kemam- 
puan untuk mendapatkan hutang dari kreditur. Perusahaan dengan aset yang besar akan memiliki agunan yang semakin tinggi, sehingga akan dapat lebih mudah memperoleh kredit.

Perusahaan yang semakin besar akan cernderung memiliki stabilitas dan pengalaman yang lebih baik, dibandingkan dengan perusahaan yang kecil. Faktor ini menjadi daya tarik dan kepercayaan investor untuk menginvestasikan dananya pada perusahaan tersebut. Kepercayaan ini menjadi ini menjadi modal penting bagi perusahaan untuk memperoleh pendanaan dengan cara menerbitkan saham. Perusahaan besar akan lebih mudah untuk memperoleh dana dari pasar modal. Hasil penelitian ini mendukung temuan penelitian Chandra (2017), Lim (2012), Sumani (2015). Namun, temuan penelitian tidak mendukung temuan penelitian Fachrudin (2013), Hardiyanto (2013), Acaravci (2015).

\section{SIMPULAN DAN SARAN}

Berdasarkan hasil penelitian menunjukkan bahwa profitabilitas berpengaruh terhadap struktur modal dengan arah negatif. Hasil ini mengindikasikan bahwa perusahaan lebih menguatamkan pendanaan dari internal daripada ekstrnal nerupa hutang. Pertumbuhan penjualan berpengaruh terhadap struktur modal, dengan arah positif. Peningkatan penjualan akan berimplikasi pada peningkatan kapasitas produksi. Perusahaan akan memerlukan tambahan pembiayaan untuk membiayai peningkatan kebutuhan modal kerja dan investasi. Perusahaan akan menerbitkan surat hutang, ketika sumber dana internal tidak mampu memcukup kebutuhan dana yang besar. Hutang menjadi akan cenderung meningkat, sehingga struktur modl perusahaan juga akan meningkat. Ukuran perusahaan tidak berpengaruh terhadap struktur modal. Temuan penelitian mendukung pecking order theory.

Penelitian ini terbatas menginvestigasi struktur modal dengan variabel prediktor profita-bilitas, pertumbuhan penjualan dan ukuran peru-sahaan. Objek penelitian terbatas pada perusahaan yang bergerak pada industri dasar dan kimia, dengan periode pengamatan 2013-2016. Kelemahan penelitian ini tidak melakukan pembedaan perusahaan dengan melakukan penyisihan laba untuk laba ditahan dan tidak melakukan. Untuk penelitian yang akan datang diharapkan dapat melakukan pembedaan perushaan yang melakukan penyisihan laba dan tidak melakukan. Selain itu diharapkan dilakukan pengamatan untuk masingmasing industri, dengan karakteristik yang berbeda.

\section{DAFTAR PUSTAKA}

Acaravci, K. S., (2015). The Determinants of Capital Structure: Evidence from the Turkish Manufacturing Sector. International Journal of Economics and Financial Issues Vol. 5(1): 158171.

Chandra, F A., (2017). Caompany Size, Profitability, Tangibilitas, Free Cash Flow and Growh Opportunity That Affect Yhe Capital Structure in Manufacturing Company. Jurnal Manajemen Bisnis dan Kewirausahaan. Vol. 2(2): $17-26$

Christianti, A., (2006). Penentuan Perilaku Kebijakan Struktur Modal pada Perusahaan Manufaktur Di Bursa Efek Jakarta: Hipotesis Static Trade Off atau Pecking Order Theory. Simposium Nasional akuntansi 9.

Eriotis, N., (2007). How Firm Characteristics Affect Capital Structure:An Empirical Study. Journal of Managerial Finance. Vol 33 (5)

Fachrudin, A. K., (2013). Determinan Preferensi Struktur Modal Usaha Mikro dan Kecil. Ekuitas: Jurnal Ekonomi dan Keuangan. Vol. 17(3): 318 - 336

Gracia, J. L. dan Mira, F.S., (2008). Testing TradeOff and Pecking Order Theories Financing SMEs. Small Bus Econ 31: 117-136.

Hardiyanto, T. A,. Noer A. A, Azam N. Sembel, R \& Maulana, A.N., (2013). Ownership and Determinants Capital Structure of Public Listed Companies in Indonesia: a Panel Data Analysis. International Research Journal of Business Studies. Vol. 4(1).

Harmono. (2010). Pengujian Struktur Modal Optimal Melalui Hubungan Antar Variabel Leverage, Profitabilitas, dan Nilai Perusahaan. Jurnal Keuangan dan Perbankan, Vol.14(2): 400-406.

Harmono (2012). Testing of Pecking order theory throuh the relationship: earnings, capital structure dividend policy, and firm's value. Jurnal Keuangan dan Perbankan. Vol. 16(3): 358-371.

Haryanto. S., (2012). Karakteristik dan Risiko Bisnis Terhadap Kebijakan Struktur Modal Pada Perusahaan Otomotif. Jurnal Keuangan dan Perbankan. Vol. 16(2): 205-214.

Haryanto. S., (2015). Determinan Capital Buffer: 
Kajian Empirik Industri Perbankan Nasional. Jurnal Modernisasi, Vol. 11(2).

Haryanto. S., (2016). Determinan Permodalan Bank Melalui Profitabilitas, Risiko, Ukuran Perusahaan, Efisiensi Dan Struktur Aktiva. Jurnal Ekonomi dan Bisnis (JEB) Vol. 19(1).

Komara, A., Hartoyo, S. dan Andati, T. (2014). Analisis Pengaruh Struktur Modal Terhadap Kinerja Keuangan Perusahaan. Jurnal Keuangan dan Perbankan, Vol. 20(1): 10-21.

Krasauskaite, A., (2011). Capital Structure of SMEs: Does Firm Size Matter? Empirical Investigation of Baltic Countries. Thesis. Department of Aconomics and Business Aarhus University. Baltic.

Lim, T. C., (2012). Determinants Of Capital Structure Empirical Evidents From Financial Services Listed Firms In China. International Journal of Economics and Finance 4(3): 191-203.

Murhadi, R W., (2011). Determinan Struktur Modal: Studi di Asia Tenggara. Jurnal Manajemen $\mathcal{E}$ Kewirasusahaan. Vol. 13 (2): 91-98.

Myers, S., (1984). The Capital Structure Puzzle. The Journal of Finance, 39 (3): 575-592.

Myers, S and Majluf. (1984). Corporate Financing and Investment Decision When Firms have Information Investors Do not Have. Journal of Finance Economics 13: 187-221.

Nugraha, A. A., (2013). Analisis Pengaruh Struktur Modal Terhadap Kinerja Perusahaan Yang Tergabung Dalam Indeks Kompas 100. Management Analysis Journal. Vol. 2 (1).

Prabansari, Y dan Kusuma, H., (2005). FaktorFaktor yang mempengaruhi Struktur Modal Perusahaan Manufaktur Go Public Di Bursa Efek Jakarta. Jurnal Sinergi: Kajian Bisnis dan Manajemen Edisi Khusus on Finance, 2005: 115.

Proença. P, Laureano. MS. Raul, Laureano, M.S. Luis, (2014). Determinants of capital structure and the 2008 financial crisis: evidence from Portuguese SMEs. 10th International Strategic Management Conference Procedia - Social and Behavioral Sciences 150 (2014): 182 - 191.

Pujiharjanto, C. Nilmawati. Gusaptono, R. H., (2014). Identifikasi Variabel Penentu Struktur Modal dan Adjustment to Target Capital Structure: Trade -off Theory. Jurnal Keuangan dan Perbankan. Vol. 18(3): 358-369

Rochmah. M. A. dan Asyik. F. N., (2015). Pengaruh Kinerja dan Keputusan Investasi Terhadap Struktur Modal dan Nilai Perusahaan. Jurnal Ilmu \& Riset Akuntansi Vol. 4(4).

Ruslim. H., (2009). Pengujian Struktur Modal (Teori Pecking Order): Analisis Empiris Terhadap Saham di LQ 45. Jurnal Bisnis dan Akuntansi. Vol. 11 (3): 209-221

Sari, H. D. Djazuli, A. dan Aisjah, S., (2013). Determinan Struktur Modal dan Dampaknya terhadap Nilai Perusahaan (Studi pada Perusahaan Makanan dan Minuman di Bursa Efek Indonesia). Jurnal Aplikasi Manajemen, Vol. 11

Sheikh. N.A., dan Wang, Z., (2011). Determinants of Capital Structure An Empirical Study of Firms in Manufacturing Industry of Pakistan. Journal of Managerial Finance. Vol. 37(2): 117133.

Sitorus. M. P., (2013). Struktur Modal Optimal Pada Perusqahaan Telekomunikasi Indonesia. Jurnal Keuangan dan Perbankan, Vol.17 (3): 400-406

Song. H., (2005). Capital Structure Determinants, An Empircal Study of Swedish Companies. CESIS Electrinic Working Paper Series. Paper No. 25 Januari 2005.

Subagyo. H., (2011). Efektifitas Kebijakan Struk-tur Modal Dalam Meningkatkan Nilai Perusahaan (Capital Structure Policy Effectiveness in Enhancing Firm Value). Jurnal Bisnis dan Ekonomi (JBE) Vol. 18(1): 59-68.

Sumani. (2015). Determinan Struktur Modal Dan Nilai Perusahaan Pertambangan Pasca UU No. 4 Tahun 2009. Ekuitas: Jurnal Ekonomi dan Keuangan, Vol. 19(1): 24-41

Wiliandri, R., (2011). Pengaruh Blockholder Ownership dan Firm Size terhadap Kebijakan Hutang Perusahaan. Jurnal Ekonomi Bisnis Th. 16(2).

Wimelda, L dan Marlinah, A., (2013). Variabelvariabel yang mempengaruhi Struktur Modal pada Perusahaan Publik Sektor Non Keuangan. Jurnal Media Bisnis Edisi Khusus November 2013.

Vries, D.A., (2010). The Effect of Firm Characteristics and Economic Factors on Capital 
Accounting and Financial Review

Vol. 1 (1) 2018: 36-45

Structures: A South African Study. The

Business Review, Cambridge, 15(1): 205-211. 